6396

Research Article

Journal of Extension Education

Vol. 31 No. 4, 2019

DOI:https://doi.org/10.26725/JEE.2019.4.31.6396-6400

\title{
Role of Advertisements on the Promotion of Use of Bio-fertilizers in Coimbatore District of Tamil Nadu, India
}

\author{
K. Sathiyabamavathy ${ }^{1}$ and C. Sekhar ${ }^{2}$
}

\begin{abstract}
In recent days, Bio-Fertilizers are gaining importance as organic input in sustainable agriculture and its applications. Since the excessive application of chemical fertilizers at field affects the physical properties of soil such as infiltration, soil aeration, soil structure and bulk density, its applications are slowly replaced or it is reduced to certain extent and the farmers had the habit of applications of BioFertilizers. To gain its applications, promotional measures become imperative. In order to promote BioFertilizers among the farmers, the leading producers have been using many sales promotional activities. One such promotional activity is "Advertising". This paper investigates the role of advertisements in creating awareness about the use of Bio-Fertilizers.
\end{abstract}

Keywords: Advertisement, Bio-Fertilizers; Awareness Creation; Tamil Nadu

\section{INTRODUCTION}

Experience has shown that highyielding crop varieties require more chemical fertilizers and other inputs for improving production (Ghosh et al., 2003). Consequently, the farmers are forced to spend a significant portion of their resources on fertilizers. Due to their inherent financial strain, they are unable to procure these inputs in time and apply them to their crops. More importantly, the continuous application of chemical fertilizer also causes soil and water pollution. Above all, there also a gap between the demand and supply of chemical fertilizers more particularly, nitrogenous fertilizers. In order to address all these issues, Bio-Fertilizers are considered a suitable sustainable alternative, which also supports organic agriculture (Mercykutty and Karippai, 2000).

Tamil Nadu is a forerunner in BioFertilizer production and use. Advertisements create contact and ensure co-operation between sales associates and buyers, which gives a message to the customer at the right time at a reasonable cost, which helps to develop market communication.

${ }^{1}$ Department of Tourism Management, Avinashilingam Institute of Home Science and Higher Education for women, Coimbatore-641043 and ${ }^{2}$ Department of Agricultural Economics, Tamil Nadu Agricultural University, Coimbatore-641003 
Role of Advertisements on the Promotion of Use of Bio-fertilizers in Coimbatore District of Tamil Nadu, India

Sales promotional activities also influence Bio-Fertilizers purchases. Significantly, the number of Bio-Fertilizers manufacturers in India spends more on advertising campaigns. Advertisements plays a vital role in the promotion of Bio-Fertilizers and hence a study was taken up towards how they help to promote Bio-Fertilizers. The findings of this study would help determine the effectiveness of the advertisement of Bio-Fertilizers in terms of area coverage. These results also would help the production units in making right decisions related to its advertising strategies.

\section{METHODOLOGY}

Selected places of Western part of Coimbatore district in Tamil Nadu in the taluks of Avinashi, Pollachi, Udumalpet and Mettupalayam were chosen at random to assess the awareness about Bio-Fertilizers, to find out the respondents' choice of the medium of advertising for the products of Bio-Fertilizers, to examine the effectiveness of advertisement on consumption of BioFertilizers and to suggest the choice of best advertising medium. 150 was the sample size. A multiple linear regression equation was fitted to estimate the extent of influence of the advertising method.

\section{FINDINGS AND DISCUSSION}

To create awareness among the consumers, effective promotional strategies are required. Age is supposed to have a positive influence on the level of an advertisement on Bio-Fertilizers, which may influence the decision-making behaviour regarding the purchase and usage of Bio-Fertilizers. In the present study, the influence of advertisement on the purchase of Bio-Fertilizers revealed that the age, education, total monthly income of a household and occupational status would influence the decision-making behaviour regarding the purchase and usage of BioFertilizers (Table 1). Bio-Fertilizers influenced 64.11 per cent of the consumers in Avinashi

Table 1.

Influence of Advertisements on Purchase of Bio-Fertilizers

\begin{tabular}{|c|c|c|c|c|c|c|}
\hline \multirow[b]{2}{*}{ SI. No. } & \multirow{2}{*}{$\begin{array}{l}\text { Age group in } \\
\text { years }\end{array}$} & \multicolumn{5}{|c|}{ Number of Consumers Influenced by Advertisements } \\
\hline & & $\begin{array}{c}\text { Avinashi } \\
\text { Taluk }\end{array}$ & $\begin{array}{l}\text { Pollachi } \\
\text { Taluk }\end{array}$ & \begin{tabular}{|c|} 
Udumalpet \\
Taluk
\end{tabular} & $\begin{array}{c}\text { Mettupalayam } \\
\text { Taluk }\end{array}$ & Total \\
\hline 1. & $\begin{array}{l}\text { Young age } \\
\text { (<40 years })\end{array}$ & $08(20.51)$ & $07(18.42)$ & $07(19.44)$ & 07(18.92) & $29(19.33)$ \\
\hline 2. & \begin{tabular}{|l|} 
Middle age \\
( $40-50$ years)
\end{tabular} & $25(64.11)$ & $24(63.16)$ & $23(63.89)$ & $24(64.86)$ & $96(64.00)$ \\
\hline 3. & $\begin{array}{l}\text { Old age } \\
\text { (> 50 years) }\end{array}$ & 06 (15.38) & $07(18.42)$ & 06 (16.67) & 06 (16.22) & $25(16.67)$ \\
\hline Total & & 39 (100) & $38(100)$ & $36(100)$ & 37 (100) & $150(100)$ \\
\hline
\end{tabular}

(Figures in Parentheses Indicate Percentage to Total) 
Taluk who were in the middle age group, followed by a young age group (20.51 per cent) and old age group (15.38 per cent). In Pollachi Taluk, 63.16 per cent of the middle age groups were influenced by the advertisement, followed by the young age group (18.42 per cent).

In Udumalpet Taluk and Mettupalayam Taluk middle age groups were influenced by advertisements at 63.89 per cent and 64.86 per cent, respectively. Here, the effect of advertisement on purchasing the Bio-Fertilizers by the old age group was low, which might be due to less exposure to mass media by the old age group and also their loyalty to the Bio-Fertilizers, which are unbranded and considered to be available locally. It is also important to assess how the promotional strategy that impacts on the salaried and self employed and the housewives who are actively involved in farming activities.
It is found out that overall, 66.67 per cent of the housewives who have been influenced by advertisements belonged to the unemployed category followed by those of salaried category with only 32 per cent and selfemployed category with only 1.33 per cent. It could be interpreted that the percentage of the self-employed people who were influenced by the advertisement was very less. In the case of unemployed homemakers, the influence of advertisement was intense, since this group of consumers can devote much time to view and listen to the advertisement exhibited in the mass media like television. However, it is important to assess the sources of awareness about the Bio-Fertilizers to the consumers are also important. For that different methods are being practiced.

The advertisements of Bio-Fertilizers are typically carried out through Field Demonstrations, Group Meetings, Radio, Calendar and through Cloth banners. The data

Table 2.

Estimation of Linear Regression Model

\begin{tabular}{|c|l|c|c|c|c|}
\hline SI.No. & \multicolumn{1}{|c|}{ Particulars } & Co-efficient & $\begin{array}{c}\text { Standard } \\
\text { Error }\end{array}$ & t value & Remarks \\
\hline 1. & Constraint & 28.581 & 55.67 & 0.4415 & NS \\
\hline 2. & Quality $\left(\mathrm{X}_{1}\right)$ & 107.00 & 17.99 & 5.947 & $* *$ \\
\hline 3. & Availability $\left(\mathrm{X}_{2}\right)$ & 19.075 & 16.79 & 1.136 & NS \\
\hline 4. & Package $\left(\mathrm{X}_{3}\right)$ & 8.4545 & 19.09 & 0.443 & NS \\
\hline 5. & Price $\left(\mathrm{X}_{4}\right)$ & 13.70 & 8.544 & 1.542 & NS \\
\hline 6. & Advertising index $\left(\mathrm{X}_{5}\right)$ & 135.49 & 26.22 & 5.168 & $* *$ \\
\hline 7. & Family Size $\left(\mathrm{X}_{6}\right)$ & 95.041 & 11.70 & 8.126 & $* *$ \\
\hline
\end{tabular}

$N=150 ; R^{2}=0.9064 ;^{* *}=$ Significant at 1 per cent level; $N S=$ Non Significant 
Role of Advertisements on the Promotion of Use of Bio-fertilizers in Coimbatore District of Tamil Nadu, India

Table 3.

Estimates of Linear Probability Model for Awareness about Bio-Fertilizers

\begin{tabular}{|c|l|c|c|c|c|}
\hline $\begin{array}{c}\text { Sl. } \\
\text { No. }\end{array}$ & \multicolumn{1}{|c|}{ Particulars } & Co-efficient & $\begin{array}{c}\text { Standard } \\
\text { Error }\end{array}$ & t value & Remarks \\
\hline 1. & Intercept & 0.02661 & 0.07967 & 0.3340 & NS \\
\hline 2. & Educational Level $\left(\mathrm{X}_{1}\right)$ & 0.02585 & 0.004106 & 6.296 & ${ }^{* *}$ \\
\hline 3. & Income $\left(\mathrm{X}_{2}\right)$ & 0.02539 & 0.008370 & 3.034 & ${ }^{* *}$ \\
\hline 4. & Age $\left(\mathrm{X}_{3}\right)$ & -0.0058 & 0.001985 & -2.941 & ${ }^{* *}$ \\
\hline 5. & Field Demonstrations $\left(\mathrm{X}_{4}\right)$ & 0.4025 & 0.03270 & 12.311 & ${ }^{* *}$ \\
\hline 6. & Group Meetings $\left(\mathrm{X}_{5}\right)$ & 0.3794 & 0.3245 & 11.695 & ${ }^{* *}$ \\
\hline 7. & Radio $\left(\mathrm{X}_{6}\right)$ & 0.0021 & 0.01271 & 0.171 & NS \\
\hline
\end{tabular}

$N=180 ; R^{2}=0.9263 ;{ }^{* *}=$ Significant at 1 per cent level; Log likelihood $=0.21783 ; N S=$ Non Significant

related to the source of awareness of BioFertilizers were collected and analysed.

Among the 200 respondents, only 180 respondents used Bio-Fertilizers. Hence the reasons for not using the Bio-Fertilizers were collected from 20 respondents who were using some other fertilizers. It was indicated that field demonstrations played a vital role in creating awareness about Bio-Fertilizers, followed by Group Meetings (39.44 per cent). However, the awareness through radio, calendar, and cloth banners was inferior. The field demonstrations on creating awareness were mainly due to secure access to messages even to the illiterates.

The co-efficient of multiple linear determination $\left(R^{2}\right)$ was found to be 0.9064 , i.e., the variables included in the function explained 90.64 per cent of the variation in the use of Bio-Fertilizers by the consumers date in. Linear Regression Model was applied to find out the use of Bio-Fertilizers by the sample consumers. Data in Table 2 state that among the variables, quality of BioFertilizers, advertising index, and family size shows a positive and exceedingly significant effect on the purchase of Bio-Fertilizers by the consumers. The results revealed that an increase in one point in quality would increase the purchase of Bio-Fertilizers by Rs.107 in a year.

The regression coefficient for the advertising index was 135.49, indicating that an increase in one score of advertising index increases the use of Bio-Fertilizers by Rs.135.49, and the family size also significantly influenced the purchase of Bio-Fertilizers. The price of Bio-Fertilizers, Packages, and the availability of Bio-Fertilizers were not influencing the purchase of BioFertilizers. 
Followed by the Usage of BioFertilizers by the sample consumers, the Linear Probability model was applied to find out the awareness about Bio-Fertilizers among the respondents, and the results were analysed and the details are presented in Table 3.

The variables included in the function explained that the coefficient of multiple determinations (R2) arrived at was 0.9263 indicated that 93 percent of the variation in creating the awareness of Bio-Fertilizers among the respondents by the independent variables included in the study. It is concluded that among the independent variables, educational level, income, field demonstrations, and group meetings had a positive influence on creating awareness among the respondents, and these variables were found to be significant at one per cent level. Educational status and monthly income of the households were also positive and significant, holding other variables at constant in creating awareness.

\section{CONCLUSION}

The present study has revealed that field demonstration was the most effective medium of advertisement as perceived and experienced by the consumers in terms of effectiveness and a significant source of awareness. It is also observed that an increase in the sale of Bio-Fertilizers may not be attributed to advertisements alone, and there are several other sales promotional activities. It is concluded that among various promotional strategies, field demonstration was found to have a more significant influence in creating awareness about BioFertilizers. Hence suitable strategies should be developed to popularize Bio-Fertilizers among the residents through media for sustainable development.

\section{REFERENCES}

Ghosh P.K, Dayal. D, Mandal, KG, Wanjari, RH, \& Hati, KM. (2003).Optimization of fertilizer schedules in fallow and groundnutbased cropping systems and an assessment of system sustainability. Field Crops Research. 80(2):83-98. DOI: 10.1016/ s0378-4290(02)00170-3

Mercykutty, M.J. \& Karippai, R.K. (2000), Adoption of Bio-Fertilizers Technology. Journal of Extension Education, 11: 28092811. 